\section{Trunk Sprouting and Growth of Citrus as Affected by NAA, Aluminum Foil, and Plastic Trunk Wraps}

\author{
Ed Stover ${ }^{1,2}$, Scott Ciliento, and Monty Myers \\ University of Florida, Indian River Research and Education Center, 2199 \\ South Rock Road, Ft. Pierce, FL 34945-3138
}

Additional index words. naphthaleneacetic acid, Sprout Saver, young tree care

\begin{abstract}
In spring 1999, a commercial NAA (1-naphthaleneacetic acid) preparation for trunk sprout inhibition was compared with a corrugated plastic trunk wrap, aluminum foil wrap, bimonthly hand removal of sprouts, use of NAA preparation plus bimonthly hand removal when sprouts appeared, and a nontreated control. Three recently planted groves on three different rootstocks ['Midsweet' orange (Citrus sinensis)] on Swingle citrumelo (Citrus paradisi $\times$ Poncirus trifoliata), 'Valencia' orange on Volkamer lemon (Volk, Citrus limon), and 'Minneola' tangelo (Citrus paradisi $\times C$. reticulata) on Smooth Flat Seville (SFS, Citrus hybrid) received each of the treatments in a randomized complete block experimental design with trees blocked by initial height and circumference. Every 2 months, sprouts were counted on each tree and removed from the hand removal treatments. After 1 year, all sprouts were removed and counted and height and circumference of trees was determined. Across all experiments, $82 \%$ to $100 \%$ of nontreated trees produced trunk sprouts and all sprout control methods significantly reduced sprouts per tree. NAA treatments were never significantly less effective at sprout suppression than the wraps at the $P=0.05$ level, although in two experiments, wraps were more effective than NAA at $P=0.10$. Time of sprout appearance varied between the three experimental blocks. Plastic and foil trunk wraps enhanced development of trunk circumference compared with nontreated controls in 'Midsweet'/Swingle and 'Valencia'/ Volk. Greater trunk circumference resulted from use of wraps versus NAA in all three experiments, which appeared unrelated to differential sprout suppression. In these experiments, it appears that either wraps enhanced tree development beyond the suppression of sprouts or NAA influence on tree metabolism somewhat reduced trunk growth. The economics of the sprout suppression methods are also discussed.
\end{abstract}

Citrus trees in commercial Florida orchards are developed with $0.30 \mathrm{~m}$ to as much as $0.75 \mathrm{~m}$ of bare trunk before the lowest branch (Brown, 2000). Shoots growing from the trunks of young citrus trees compete with development of the desired scion canopy and their control is routine. Use of trunk wraps to reduce sprouting is typically combined with removal of any sprouts that form (Jackson, 1994). As the canopy develops and trunks become shaded, trunk sprouting becomes much less common. Shade inhibition of sprouting can be used on young trees through application of opaque wraps (Jackson, 1994). Preparations of 1-naphthaleneacetic acid or its ethyl ester (NAA) have been reported to reduce trunk sprouting in many tree fruits (e.g., Aldrich and Arnold, 1982; Nauer and Boswell, 1978; Raese, 1975) and formulations are labeled for such use in citrus as well as other crops (Amvac Chemical Co., 2006). The purpose of this study was to compare the

Received for publication 2 June 2006. Accepted for publication 23 July 2006.

${ }^{1}$ To whom reprint requests should be addressed. e-mail ewstover@ucdavis.edu.

${ }^{2}$ Current address: USDA ARS NCGR, One Shields Avenue, Davis, CA 95616.
Sprout-suppressing treatments. The commercial plastic tree wrap used was the Sprout Saver II (which is $20 \times 36 \mathrm{~cm}$ ) and is comprised of a double layer of corrugated plastic (white on the outside and black in the inside) to allow for ventilation (Frostproof, 2004). The tree wraps were attached with two $30.5-\mathrm{cm}$ twist ties that are supplied with the wraps. Standard weight aluminum foil was cut into $\approx 28 \times 30$-cm sections in the laboratory and were wrapped around the lower $\approx 36$ $\mathrm{cm}$ of the trunk and held in place solely by friction. NAA was used in the formulation Tre-Hold RTU (Amvac Chemical Corp., Long Beach, Calif.), which is $1.15 \%$ solution of ethyl 1-naphthalenacetate in a white latex paint carrier. This material was diluted with three volumes of water and applied to the trunk using a backpack sprayer (Solo, Newport News, Va.) from the lowest branch to the soil line in a uniform coating without puddling material around the tree base. Foil and tree wraps were maintained on trees for the duration of the experiment. NAA was applied only once.

Removing sprouts. Every two months, trunk sprouts were counted on treatment trees, were removed from the trees from the two hand-sprouting treatments, and fresh weight was determined for sprouts from each tree. One year after treatment, all sprouts were removed and fresh weight determined for sprouts from each tree.

Tree measurements. Tree heights and trunk circumferences $(25 \mathrm{~cm}$ above the soil line) were measured before treatment and used for blocking. These measurements were recorded again one year after treatment.

Economic comparisons. Costs of each sprout control treatment were compared by collecting commercial prices for materials and conducting replicated trials to determine labor required. Sprout control treatments were compared on four replicates of $20+$ trees each, with time recorded for each replicate. Trees for the economic trials were 10.7 to $21.5 \mathrm{~mm}$ in diameter, were spaced at $3.85 \mathrm{~m}$ within the row, and procedures were conducted in a single row for each treatment. Use of aluminum foil was compared using: 1) packaged $30.5 \times 27.3-\mathrm{cm}$ precut squares; and 2 ) a $308-\mathrm{m}$ roll which was torn into $\approx 28 \times$ $30-\mathrm{cm}$ squares before use with preparation also timed in replicates. NAA solution use per tree was calculated by beginning with a known volume and determining number of trees covered. Labor cost estimates were calculated at $\$ 10, \$ 12.5$, and $\$ 15$ per hour.

Statistical analysis. Data comparing percentage of trees producing trunk sprouts were commercial production of Florida citrus.

\section{dy.}

Table 1. Characteristics of orchards used in this study.

\begin{tabular}{|c|c|c|c|c|c|}
\hline Orchard & Cultivar & Rootstock ${ }^{\mathrm{z}}$ & Planted & Soil type ${ }^{y}$ & $\begin{array}{c}\text { Trunk sprout treatment } \\
\text { application date }\end{array}$ \\
\hline 1 & Midsweet & Swingle & October 1997 & Pineda & 30 Mar. 1999 \\
\hline 2 & Valencia & Volkamer lemon & October 1998 & Riviera & 30 Mar. 1999 \\
\hline 3 & Minneola & Smooth Flat Seville & October 1997 & Wabbasso & 1 Apr. 1999 \\
\hline
\end{tabular}

${ }^{\mathrm{z}}$ Swingle $=$ Swingle citrumelo $($ Citrus paradisi $\times$ Poncirus trifoliata $)$; Volkamer lemon = Citrus limon: Smooth Flat Seville = an unidentified Citrus hybrid.

${ }^{y}$ Predominant soil type in each experimental orchard is listed, but small inclusions of related soil types were present. All soil types are fine sands, have a hardpan, and soils are bedded to increase rooting depth. 
subjected to $\chi^{2}$ analysis using the of FREQ procedure of SAS (SAS Institute, Cary, N.C.). All other data were analyzed using the GLM procedure of SAS; mean separation was determined using DMRT at $P \leq 0.05$ and contrast analyses were conducted.

\section{Results and Discussion}

Control of sprouting. Across all experiments, $82 \%$ to $100 \%$ of nontreated trees produced trunk sprouts. In contrast analyses, all sprout control methods significantly reduced sprouts per tree in all three experiments (Tables 2, 3, and 4). Use of aluminum foil reduced sprouts extremely effectively, resulting in only a single trunk sprout across all three experiments. The plastic trunk wrap was never statistically different from the aluminum foil treatment, although $27 \%$ of the Valencia trees treated with plastic wraps produced sprouts in experiment 2 versus $9 \%$ of the trees wrapped with aluminum foil (Table 3). NAA treatments were never significantly less effective than the wraps at the $P=0.05$ level; however, the $P$ values for this contrast were 0.1001 in 'Valencia'/Volk (Table 3) and 0.0548 in 'Minneola'/SFS (Table 4). It should be noted that although the dilution of Tre-Hold used in the experiment was included in the label for citrus 1999, current labels specify only undiluted application of this product to nonbearing citrus (Amvac Chemical Co., 2006). Published studies of NAA use for trunk sprout control in apple nursery stock show some rate responsiveness (Dozier and Hollingsworth, 1976) so sprout suppression may well be greater with a higher rate of NAA.

Bimonthly removal of the sprouts from the nontreated plants significantly reduced total sprout production in 'Midsweet'/Swingle and 'Valencia'/Volk (Tables 2 and 3), but not in 'Minneola'/SFS (Table 4). Interestingly, removal of the sprouts from the NAA-treated plants significantly increased total sprout production in 'Minneola'/SFS (Table 4). According to contrast analysis, which combined nontreated and NAA-treated trees, total fresh weight of sprouts in the 1 -year trial was reduced by hand removal in 'Valencia'/Volk (Table 3) but increased in 'Minneola'/SFS (Table 4).

Time course of sprouting. Time of sprout appearance varied between the three experiments. In 'Midsweet'/Swingle, the nontreated trees displayed greatest sprout production between 1 Aug. and 1 Oct. with negligible additional sprouting, whereas NAA treated trees did not display sprout development until the spring of the year after treatment (Fig. 1A). The 'Valencia'/Volk trees displayed significant sprout development in the spring and summer of the first year, whereas NAAtreated trees permitted some sprout development beginning in the summer and fall, which was not statistically significantly greater than the wrap treatments until the next winter (Fig. 1B). The 'Minneola'/SFS trees all had less than one sprout per tree until the spring of the year after treatment (Fig. 1C).

Table 2. Response of 'Midsweet' orange on Swingle citrumelo rootstock to trunk sprout management practices. $^{\mathrm{Z}}$

\begin{tabular}{|c|c|c|c|c|c|c|}
\hline & & $\begin{array}{c}\text { Trees } \\
\text { with } \\
\text { sprouts }(\%)^{y}\end{array}$ & $\begin{array}{l}\text { Sprouts } \\
\text { per } \\
\text { plant }\end{array}$ & $\begin{array}{c}\text { Fresh } \\
\text { wt all } \\
\text { sprouts }(\mathrm{g})\end{array}$ & $\begin{array}{c}\text { Final } \\
\text { trunk } \\
\text { circum. }(\mathrm{cm})\end{array}$ & $\begin{array}{c}\text { Final } \\
\text { tree } \\
\text { ht }(\mathrm{cm})\end{array}$ \\
\hline 1 & Nontreated, no removal & 91 & $14.9 \mathrm{a}^{\mathrm{x}}$ & $131.2 \mathrm{a}$ & $9.5 \mathrm{~b}$ & $128 \mathrm{a}$ \\
\hline 2 & Nontreated, bimonthly removal & 82 & $4.1 \mathrm{~b}$ & $100.8 \mathrm{ab}$ & $10.5 \mathrm{ab}$ & $139 \mathrm{a}$ \\
\hline 3 & NAA no removal & 27 & $2.2 \mathrm{~b}$ & $98.4 \mathrm{ab}$ & $9.9 \mathrm{ab}$ & $135 \mathrm{a}$ \\
\hline 4 & NAA bimonthly removal & 18 & $1.0 \mathrm{~b}$ & $18.7 \mathrm{ab}$ & $9.8 \mathrm{ab}$ & $128 \mathrm{a}$ \\
\hline 5 & Aluminum foil wrap & 0 & $0.0 \mathrm{~b}$ & $0.0 \mathrm{~b}$ & $10.4 \mathrm{ab}$ & $138 \mathrm{a}$ \\
\hline 6 & Plastic trunk wrap & 9 & $0.1 \mathrm{~b}$ & $1.4 \mathrm{~b}$ & $10.8 \mathrm{a}$ & $144 \mathrm{a}$ \\
\hline \multicolumn{7}{|c|}{$P$ values from contrasts } \\
\hline & 4 vs. 1 and 2) & & 0.0001 & 0.1392 & 0.5774 & 0.6892 \\
\hline & Wraps vs. control (5 and 6 vs. 1and 2) & & 0.0001 & 0.0038 & 0.0731 & 0.2238 \\
\hline & NAA vs. wraps ( 3 and 4 vs. 5 and 6 ) & & 0.2419 & 0.1365 & 0.0203 & 0.1081 \\
\hline & Removal vs. not ( 2 and 4 vs. 1 and 3 ) & & 0.0001 & 0.1563 & 0.1961 & 0.7709 \\
\hline & Plastic vs. foil (5 vs. 6 ) & & 0.9610 & 0.9795 & 0.4674 & 0.4397 \\
\hline
\end{tabular}

${ }^{2}$ Trees were planted Oct. 1997 and treatments applied 30 Mar. 1999. Foil, plastic trunk wrap, and NAA (applied at $0.29 \%$ in latex formulation) were applied to the lower $\approx 36 \mathrm{~cm}$ of trunk. Table presents tree response for one year after treatment.

${ }^{\mathrm{y}} \chi^{2}$ test for difference between treatments was significantly different at $P=0.0073$.

${ }^{x}$ Means within a column not followed by the same letter were found significantly different by DMRT at $P \leq 0.05$.

Table 3. Response of 'Valencia' orange on Volkamer lemon rootstock to trunk sprout management practices. ${ }^{\mathrm{z}}$

\begin{tabular}{|c|c|c|c|c|c|c|}
\hline & & $\begin{array}{c}\text { Trees } \\
\text { with } \\
\text { sprouts }(\%)^{\mathrm{y}}\end{array}$ & $\begin{array}{l}\text { Sprouts } \\
\text { per } \\
\text { plant }\end{array}$ & $\begin{array}{c}\text { Fresh } \\
\text { wt all } \\
\text { sprouts (g) }\end{array}$ & $\begin{array}{c}\text { Final } \\
\text { trunk } \\
\text { circum. }(\mathrm{cm})\end{array}$ & $\begin{array}{c}\text { Final } \\
\text { tree } \\
\mathrm{ht}(\mathrm{cm})\end{array}$ \\
\hline 1 & Nontreated, no removal & 90 & $48.6 \mathrm{a}^{\mathrm{x}}$ & $374.9 \mathrm{a}$ & $8.2 \mathrm{~b}$ & $114 \mathrm{~b}$ \\
\hline 2 & Nontreated, bimonthly removal & 91 & $9.0 \mathrm{~b}$ & $75.9 \mathrm{bc}$ & $9.0 \mathrm{~b}$ & $120 \mathrm{ab}$ \\
\hline 3 & NAA no removal & 55 & $14.0 \mathrm{~b}$ & $245.1 \mathrm{ab}$ & $8.3 \mathrm{~b}$ & $115 \mathrm{ab}$ \\
\hline & NAA bimonthly removal & 73 & $3.3 \mathrm{~b}$ & $33.3 \mathrm{c}$ & $9.6 \mathrm{ab}$ & $123 \mathrm{ab}$ \\
\hline & Aluminum foil wrap & 9 & $0.1 \mathrm{~b}$ & $0.0 \mathrm{c}$ & $9.5 \mathrm{ab}$ & $122 \mathrm{ab}$ \\
\hline & Plastic trunk wrap & 27 & $1.1 \mathrm{~b}$ & $73.4 \mathrm{bc}$ & $10.5 \mathrm{a}$ & $130 \mathrm{a}$ \\
\hline \multicolumn{7}{|c|}{$P$ values from contrasts } \\
\hline & NAA vs. control (3 and 4 vs. 1 and 2) & & 0.0001 & 0.1996 & 0.4731 & 0.6241 \\
\hline & Wraps vs. control ( 5 and 6 vs. 1 and 2 ) & & 0.0001 & 0.0062 & 0.0061 & 0.0841 \\
\hline & NAA vs. wraps ( 3 and 4 vs. 5 and 6 ) & & 0.1001 & 0.1237 & 0.0357 & 0.2055 \\
\hline & Removal vs. not ( 2 and 4 vs. 1 and 3 ) & & 0.0001 & 0.0003 & 0.0411 & 0.1953 \\
\hline & Plastic vs. foil (5 vs. 6$)$ & & 0.8838 & 0.4319 & 0.1586 & 0.2907 \\
\hline
\end{tabular}

${ }^{2}$ Trees were planted Oct. 1998 and treatments applied 30 Mar. 1999. Foil, plastic trunk wrap, and NAA (applied at $0.29 \%$ in latex formulation) were applied to the lower $\approx 36 \mathrm{~cm}$ of trunk. Table presents tree response for 1 year after treatment.

${ }^{y} \chi^{2}$ test for difference between treatments was significantly different at $P=0.054$.

${ }^{x}$ Means within a column not followed by the same letter were found significantly different by DMRT at $P \leq 0.05$.

Table 4. Response of 'Minneola' tangelo on Smooth Flat Seville rootstock to trunk sprout management practices. ${ }^{\mathrm{z}}$

\begin{tabular}{|c|c|c|c|c|c|c|}
\hline & & $\begin{array}{c}\text { Trees } \\
\text { with } \\
\text { sprouts }(\%)^{y}\end{array}$ & $\begin{array}{l}\text { Sprouts } \\
\text { per } \\
\text { plant }\end{array}$ & $\begin{array}{c}\text { Fresh } \\
\text { wt all } \\
\text { sprouts (g) }\end{array}$ & $\begin{array}{c}\text { Final } \\
\text { trunk } \\
\text { circum. }(\mathrm{cm})\end{array}$ & $\begin{array}{l}\text { Final } \\
\text { tree } \\
\mathrm{ht}(\mathrm{cm})\end{array}$ \\
\hline 1 & Nontreated, no removal & 100 & $5.2 \mathrm{a}^{\mathrm{x}}$ & $11.3 \mathrm{ab}$ & $11.1 \mathrm{a}$ & $155 \mathrm{ab}$ \\
\hline 2 & Nontreated, bimonthly removal & 89 & $3.7 \mathrm{a}$ & $16.5 \mathrm{a}$ & $10.4 \mathrm{a}$ & $144 \mathrm{ab}$ \\
\hline 3 & NAA no removal & 13 & $0.3 \mathrm{~b}$ & $0.0 \mathrm{~b}$ & $10.2 \mathrm{a}$ & $134 \mathrm{~b}$ \\
\hline 4 & NAA bimonthly removal & 67 & $4.0 \mathrm{a}$ & $14.2 \mathrm{a}$ & $10.8 \mathrm{a}$ & $141 \mathrm{ab}$ \\
\hline 5 & Aluminum foil wrap & 0 & $0.0 \mathrm{~b}$ & $0.0 \mathrm{~b}$ & $11.2 \mathrm{a}$ & $163 \mathrm{a}$ \\
\hline 6 & Plastic trunk wrap & 0 & $0.0 \mathrm{~b}$ & $0.0 \mathrm{~b}$ & $12.0 \mathrm{a}$ & $154 \mathrm{ab}$ \\
\hline \multicolumn{7}{|c|}{$P$ values from contrasts } \\
\hline & NAA vs. control ( 3 and 4 vs. 1 and 2 ) & & 0.0376 & 0.0992 & 0.6257 & 0.1329 \\
\hline & Wraps vs. control (5 and 6 vs. 1 and 2) & & 0.000 & & & 0.2227 \\
\hline & NAA vs. wraps ( 3 and 4 vs. 5 and 6 ) & & 0.0548 & 0.0840 & 0.0622 & 0.0088 \\
\hline & Removal vs. not ( 2 and 4 vs 1 and 3 ) & & 0.3098 & 0.0199 & 0.8549 & 0.7821 \\
\hline & Plastic vs. foil (5 vs. 6 ) & & 1.0000 & 1.0000 & 0.2861 & 0.4156 \\
\hline
\end{tabular}

${ }^{2}$ Trees were planted Oct. 1997 and treatments applied 1 Apr. 1999. Foil, plastic trunk wrap, and NAA (applied at $0.29 \%$ in latex formulation) were applied to the lower $\approx 36 \mathrm{~cm}$ of trunk. Table presents tree response for 1 year after treatment.

${ }^{\mathrm{y}} \chi^{2}$ test for difference between treatments was significantly different at $P=0.067$.

${ }^{x}$ Means within a column not followed by the same letter were found significantly different by DMRT at $P \leq 0.05$.

Effect on tree growth. Because trees were blocked according to tree size, all treatments began with similar trees (Tables 2, 3, and 4). At the end of the experiment, DMRT in- dicated that the plastic trunk wraps enhanced development of trunk circumference compared with nontreated controls in 'Midsweet'/ Swingle and 'Valencia'/Volk (Tables 2 and 3). 

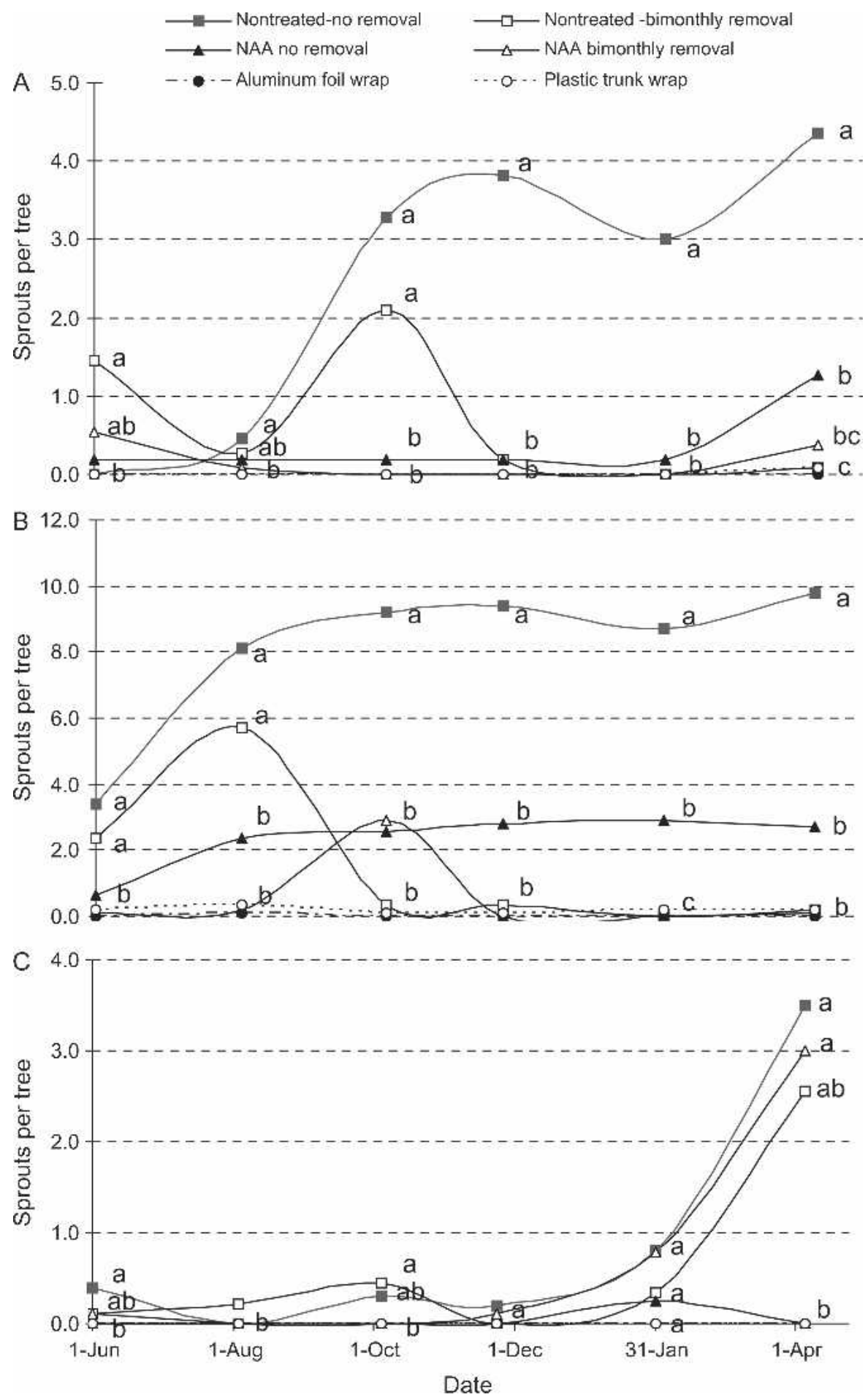

Fig. 1. Effect of sprout control treatments on time course of sprout development on young citrus trees. Foil, plastic trunk wrap, and NAA (applied at $0.29 \%$ in latex formulation) were applied to lower $\approx 36 \mathrm{~cm}$ of trunk on 30 Mar. or 1 Apr. 1999, 2 months before first data point. (A) 'Midsweet' orange on Swingle citrumelo rootstock. Trees were planted Oct. 1997. (B) 'Valencia' orange on Volkamer lemon rootstock. Trees were planted Oct. 1998. (C) 'Minneola' tangelo on Smooth Flat Seville rootstock. Trees were planted Oct. 1997.

In these two experiments, contrast analyses of both wrap treatments versus the two nontreated controls showed greater increase in trunk circumference from use of the wraps $(P$ values 0.073 for 'Midsweet'/Swingle and 0.006 for 'Valencia'/Volk) and increased tree height from the use of wraps in 'Valencia'/
More interestingly, contrast analyses demonstrate improved tree growth from use of wraps versus NAA in all three experiments. Trunk circumference from use of wraps versus NAA was increased $8 \%$ in 'Midsweet'/Swingle $(P=0.02), 12 \%$ in 'Valencia'/Volk $(P=0.04)$, and $10 \%$ in 'Minneola'/ SFS $(P=0.06)$. Although the trend was similar, effect on tree height was less evident, with $P$ value less than 0.10 only in 'Minneola'/SFS, in which trees treated with wraps were $15 \%$ taller than the NAA treated trees. Because NAA treatments often resulted in slightly more sprout development than did the wraps, we suspected that greater tree growth may have reflected better sprout suppression. However, the trunk circumference differences were unaffected by conducting analysis of variance only on trees in which no sprouts were produced (data not shown). In these experiments, it appears that either wraps enhanced tree development beyond the suppression of sprouts or NAA influence on tree metabolism somewhat reduced circumference growth.

Reduced scion growth has been previously reported in several species, including citrus, after NAA application to suppress trunk sprouts (Boswell et al., 1979; Dozier and Hollingsworth, 1976; Nauer and Boswell, 1977, 1978). NAA used for trunk sprout suppression in peaches has been reported to increase gumming with greater response at higher concentrations (Couvillon et al., 1977) and even cause substantial tree mortality in some cultivars when used at $0.05 \%$ (Aldrich and Arnold, 1982). Reduced fruit size was reported for 'Anjou' pear in which pruned scaffold limbs were treated with $1 \%$ NAA in the acid form (Raese, 1975). Although the ethyl ester form of NAA is reported to be translocated less than the sodium salt, both significantly suppressed lower budbreak when the apical portions of 'Navel' trees were treated in a greenhouse study (Nauer et al., 1978).

Economics of sprout suppression treatments. Material costs per tree varied greatly among the sprout control treatments. The plastic trunk wrap was the most expensive at $\$ 0.320 /$ tree followed by NAA at $\$ 0.122 /$ tree and aluminum foil at $\$ 0.021$ to $0.024 /$ tree (Table 5). However, the time required to apply treatments was much lower for NAA sprays than the other treatments. When cost per tree was calculated with labor at $\$ 10$ to 15 per hour, use of NAA sprays cost $\approx 35 \%$, and aluminum foil trunk wrapping cost $16 \%$ to $23 \%$ of the cost for using plastic trunk wraps.

There are several additional factors that were not included in economic calculations. Plastic trunk wraps are reported to provide modest freeze protection for young trees (Jackson, 1994), which may be of great value in some years and locations. Plastic or aluminum wraps may also afford some protection against herbicide damage to young trees (Jackson, 1994). It should be noted that no evidence of herbicide injury was seen in 
Table 5. Each treatment was applied four times to groups of 20 trees in a row with individual times recorded for each trial. ${ }^{\mathrm{z}}$

\begin{tabular}{|c|c|c|c|c|c|c|c|c|}
\hline \multirow[b]{2}{*}{ Treatment } & \multirow[b]{2}{*}{$\begin{array}{c}\text { Material } \\
\text { per tree }(\$)\end{array}$} & \multirow[b]{2}{*}{$\begin{array}{l}\text { Time per tree } \\
\text { (min) }\end{array}$} & \multicolumn{2}{|c|}{ Labor at $\$ 10 / \mathrm{hr}$} & \multicolumn{2}{|c|}{ Labor at $\$ 12.5 / \mathrm{hr}$} & \multicolumn{2}{|c|}{ Labor at $\$ 15 / \mathrm{hr}$} \\
\hline & & & $\begin{array}{l}\text { Labor cost } \\
\text { per tree }(\$)\end{array}$ & $\begin{array}{c}\text { Total cost } \\
\text { per tree }(\$)\end{array}$ & $\begin{array}{l}\text { Labor cost } \\
\text { per tree }(\$)\end{array}$ & $\begin{array}{c}\text { Total cost } \\
\text { per tree }(\$)\end{array}$ & $\begin{array}{l}\text { Labor cost } \\
\text { per tree }(\$)\end{array}$ & $\begin{array}{c}\text { Total cost } \\
\text { per tree }(\$)\end{array}$ \\
\hline Plastic trunk wrap & 0.320 & $0.370 \mathrm{a}^{\mathrm{y}}$ & $0.062 \mathrm{a}$ & $0.382 \mathrm{a}$ & $0.077 \mathrm{a}$ & $0.397 \mathrm{a}$ & $0.093 \mathrm{a}$ & $0.413 \mathrm{a}$ \\
\hline NAA & 0.122 & $0.089 \mathrm{~d}$ & $0.015 \mathrm{~d}$ & $0.137 \mathrm{~b}$ & $0.018 \mathrm{~d}$ & $0.140 \mathrm{~b}$ & $0.022 \mathrm{~d}$ & $0.144 \mathrm{~b}$ \\
\hline Aluminum foil precut & 0.024 & $0.231 \mathrm{c}$ & $0.038 \mathrm{c}$ & $0.063 \mathrm{~d}$ & $0.048 \mathrm{c}$ & $0.072 \mathrm{~d}$ & $0.058 \mathrm{c}$ & $0.082 \mathrm{~d}$ \\
\hline
\end{tabular}

${ }^{2}$ Foil, plastic trunk wrap, and NAA (applied with hand sprayer at $0.29 \%$ in latex formulation) were applied to lower $\approx 36 \mathrm{~cm}$ of trunk. Aluminum foil was compared using packaged $30.5 \times 27.3-\mathrm{cm}$ precut squares, and a $308-\mathrm{m}$ roll which was torn into $\approx 28 \times 30$-cm squares before use with preparation also timed in replicates (range, 4.7-6.1 s per sheet). Volume of NAA solution per tree averaged over several replicates and found to be $25.4 \mathrm{~mL} / \mathrm{tree}$. Costs used were: $\$ 0.32 \mathrm{per}$ wrap for plastic trunk wraps; $\$ 23.81$ per $308 \mathrm{~m}$ roll of aluminum foil; $\$ 72.36$ per 3000 precut foil sheets; and Tre-Hold RTU Sprout Inhibitor (1.15\% ethyl 1-naphthaleneacetate) at $\$ 19.29$ per L.

${ }^{\mathrm{y}}$ Means within a column not followed by the same letter were found significantly different by DMRT at $P \leq 0.05$.

any trees in this study. Wraps may foster development of damaging fungi or ant populations, which can result in substantial mortality. Some growers include routine trunk pesticide sprays for wrapped trees to avoid these problems (Indian River Citrus Growers, personal communication), but such treatments were not used in this study and no ant or fungal damage was observed. It must be noted that high winds can remove aluminum foil wraps, and in one experimental grove, $20 \%$ of the trees needed foil replacement after passage of a tropical storm. One should consider that sprout control may be needed for three years, requiring only a single application of a plastic trunk wrap (Jackson, 1994) but likely requiring two or more applications of aluminum foil or NAA. Finally, it must be noted that the differences in tree growth observed in this study may not have a substantial influence on the ultimate productivity of the trees.

\section{Literature Cited}

Aldrich, J.H. and C.E. Arnold. 1982. Sprout control of non-bearing peach with NAA. HortScience 17:378-379.

Amvac Chemical Co. 2006. Tre-Hold sprout inhibtor for citrus label. <http://www.amvacchemical.com/media/pdf/products/specimen_ labels/trehold.pdf>. June 2006

Boswell, S.B., B.O. Bergh, R.H. Whitsell, and J. Kumamoto. 1979. Reduction of rootstock sprouts on young grafted avacados with NAA. HortScience 14:57-59.

Brown, G.K. 2000. Overview of mechanical harvesting in Florida citrus. Proc. Intl. Soc. Citricult. IX Cong. 1:273-276.

Couvillon, G.A., S. Bass, B.W. Joslin, R.E. Odom, J.E. Roberson, D. Sheppard, and R. Tanner. 1977. HortScience 12:123-124.
Dozier, W.A., Jr. and M.H. Hollingsworth. 1976. Sprout control of apple nursery stock with NAA. HortScience 11:392-393.

Frostproof, 2004. Tree wraps-Sprout saver II. $<\mathrm{http}: / / \mathrm{www}$.frostproof.com/catalog/ w03.html>. Apr. 2004.

Jackson, L.K. 1994. Citrus reset management. University of Florida Extension Fact Sheet HS-142. <http://edis.ifas.ufl.edu/CH025>. June 2006.

Nauer, E.M. and S.B. Boswell. 1977. Effect of NAA on shoot growth of topworked fig trees. HortScience 12:250-251.

Nauer, E.M. and S.B. Boswell. 1978. NAA sprays suppress sprouting of newly budded citrus trees. HortScience 13:166-167.

Nauer, E.M., S.B. Boswell, and R.C. Holmes. 1978. Translocation of NAA in 'Washington' navel orange. HortScience 13:48-49.

Raese, J.T. 1975. Sprout control of apple and pear trees with NAA. HortScience 10:396398. 